Digital Soil Mapping with Limited Data 
Alfred E. Hartemink - Alex McBratney •

Maria de Lourdes Mendonça-Santos

Editors

\section{Digital Soil Mapping with Limited Data}

With a foreword by Robert J. Ahrens

至 Springer 


\section{Editors}

Alfred E. Hartemink

ISRIC - World Soil Information

6700 AJ Wageningen

The Netherlands

alfred.hartemink@wur.nl

\section{Maria de Lourdes Mendonça-Santos}

EMBRAPA-Brazilian Agricultural Research

Corporation/CNPS-The National

Centre of Soil Research

Rua Jardim Botânico. 1024 CEP.22.460-000

Rio de Janeiro-RJ, Brazil

lou.mendonca@cnps.embrapa.br
Alex McBratney

University of Sydney

McMillan Building A05

Science Rd.

NSW, Camperdown, Sydney 2006

Fac. of Agriculture

Australia

A.McBratney@usyd.edu.au

ISBN: 978-1-4020-8591-8

Library of Congress Control Number: 2008927194

\section{(c) 2008 Springer Science+Business Media B.V.}

No part of this work may be reproduced, stored in a retrieval system, or transmitted

in any form or by any means, electronic, mechanical, photocopying, microfilming, recording or otherwise, without written permission from the Publisher, with the exception of any material supplied specifically for the purpose of being entered and executed on a computer system, for exclusive use by the purchaser of the work.

Printed on acid-free paper

$\begin{array}{lllllllll}9 & 8 & 7 & 6 & 5 & 4 & 3 & 2 & 1\end{array}$

springer.com 


\section{Foreword}

Significant technological advances have been few and far between in the past approximately one hundred years of soil survey activities. Perhaps one of the most innovative techniques in the history of soil survey was the introduction of aerial photographs as base maps for field mapping, which replaced the conventional base map laboriously prepared by planetable and alidade. Such a relatively simple idea by today's standards revolutionized soil surveys by vastly increasing the accuracy and efficiently. Yet, even this innovative approach did not gain universal acceptance immediately and was hampered by a lack of aerial coverage of the world, funds to cover the costs, and in some cases a reluctance by some soil mappers and cartographers to change.

Digital Soil Mapping (DSM), which is already being used and tested by groups of dedicated and innovative pedologists, is perhaps the next great advancement in delivering soil survey information. However, like many new technologies, it too has yet to gain universal acceptance and is hampered by ignorance on the part of some pedologists and other scientists.

DSM is a spatial soil information system created by numerical models that account for the spatial and temporal variations of soil properties based on soil information and related environmental variables (Lagacheric and McBratney, 2007). Pedologists working with DSM technology are in the process of addressing questions and concerns. Some of these questions include production and processing of covariates (soil forming factors derived from remote sensing and existing soil maps), the collection of soil data, the development of soil predictions based on numerical models, and the representation of digital soil maps.

Covariates include the traditional soil forming factors of parent material, topography, vegetation, and climate. Some of the more sophisticated remote sensing techniques help glean information on the mineralogy and specific properties of the surface layers or horizons. The ever expanding application of remote sensing and associated decrease in costs open the doors for advantageous development of stronger soil covariates and improvement to the predictive utility of DSM.

Traditional soil survey has always struggled with the collection of data. The amount of soil data and information required to justify the mapping product, how to interpolate data to similar areas, and how to incorporate older data are all challenges that need further discussion. Older data often were collected with antiquated 
or imprecise terms and must be cross-referenced to current standards, but the biggest obstacle in using older data is the lack of georeferencing. Traditional soil surveys have tried to write standards for data collection, but the practicality of applying the standards is difficult and not completely satisfactory. The amount of data is dependent on the complexity of the area and the experience of the mapper among other things. DSM also needs some guides or standards that will be difficult to cultivate to meet everyone's expectations and requirements. Some of the most ardent discussions in pedology center around standards, including different soil classification systems, and seemingly fail to concentrate and evaluate the end-product, which is the soil information provided to the user. DSM is a technological advancement that has the potential to be misunderstood and thus viewed with skepticism.

Numerical models are the functions that predict soil properties or soil classes. Most of these models have been calibrated with soil samplings and have been tested over small areas. The limitation of soil sampling dense enough to capture the spatial variability presently somewhat limit the use of numerical models to for large areas.

The world's overpopulation of the human race and associated pressures on resources, necessitate the immediate need for valuable soil information to make informed decisions about the soil resource, or, at the very least, make people aware of the problems and potential problems. We do not have the time or resources to canvass the earth and gather all the soil data and information needed to make soil surveys by our traditional methods. We need to look at the data that we do have and employ new methods and new technologies to deliver information on the soil resource. At the same time we should not be enamored solely on technology without an appreciation and understanding of soil-landscape relationships, which provide the predictive tools and foundations of soil survey.

DSM has the potential to deliver the needed information and in fact may provide better and more accurate information. However, the technology of DSM must overcome the skepticism associated with any new technology in the traditional world of soil survey where new technologies have been few and far between.

The purpose of this book is to present the latest technologies, challenges, and ideas related to DSM. Papers in this book were presented at the second Global Workshop on Digital Soil Mapping for Regions and Countries with Sparse Soil Spatial Data Infrastructures, which was held in Rio de Janeiro in July 2006. The EMBRAPA CNPS (Brazilian National Soil Research Centre) hosted the meeting, and the organizing committee was co-chaired by Dr. Lou Mendonça-Santos of EMBRAPA Solos and Prof. Alex McBratney of The University of Sydney, Australia. Chapters range from overviews of the DSM technology in general to specific applications in areas without much soil information or areas where specific parameters are investigated. Case studies in different parts of the world provide the opportunity to evaluate the information and test its utility. I invite you all to engage in this new technology, keep an open mind, continue the lively discussions that have always made pedology exciting and enjoyable, and in the process strive to save our most valuable resource, the soil. 


\section{Reference}

Lagacherie, P., McBratney, A.B., 2007. Chapter 1. Spatial soil information systems and spatial soil inference systems: perspectives for Digital Soil Mapping. In: P. Lagacherie, A.B. McBratney and M. Voltz (Editors), Digital Soil Mapping: An Introductory Perspective. Developments in Soil Science, volume 31. Elsevier, Amsterdam, pp. 3-24. 


\section{Preface}

This book reports on the second of a series of global workshops on digital soil mapping held in Rio de Janeiro in July 2006 which coincided with the FIFA World Cup - so it was an exciting time to be in Brazil. The meeting was hosted by EMBRAPA Solos (Brazilian National Soil Research Centre) and the organizing committee was co-chaired by Dr. M.L. Mendonça-Santos of EMBRAPA Solos and Prof. Alex McBratney of the University of Sydney. The meeting was organised with the financial support of EMBRAPA, FAPERJ (Carlos Chagas Filho Foundation for Research Support of Rio de Janeiro State), CNPq (The National Council for Scientific and Technological Development) and CPRM (Brazilian Geological Service). There were some 100 participants from 20 countries.

The theme of the workshop was Digital Soil Mapping for Regions and Countries with Sparse Soil Spatial Data Infrastructures.

There has been considerable expansion in the use of digital soil mapping technologies and development of methodologies that improve digital soil mapping at all scales and levels of resolutions. These developments have occurred in all parts of the world in the past few years also in countries where it was previously absent. Much in the same way money and time are always short, there is almost always a shortage of data in soil research and its applications. That may lead to unsupported statements, sloppy statistics, misrepresentations and ultimately bad resource management. In digital soil mapping, maximum use is made of sparse data and this books contains several examples how that can be done.

From the Rio de Janeiro workshop we have selected 34 papers that focused on digital soil mapping methodologies and applications for areas where data are limited. The papers have been loosely grouped into the following sections (i) introductory papers, (ii) dealing with limited spatial data infrastructures, (iii) methodology development, and (iv) examples of digital soil mapping in various parts of the globe (including USA, Brazil, UK, France, Czech Republic, Honduras, Kenya, Australia). The last chapter summarises priorities for digital soil mapping. We feel this book is a logical development of the ideas presented in "Digital soil mapping - an introductory perspective", edited by Lagacherie et al., (2007) in the Developments in Soil Science Series.

Wageningen

A.E. Hartemink

Sydney

A.B. McBratney

Rio de Janeiro

M.L. Mendonça-Santos 


\section{Contents}

\section{Part I Introduction}

1 Digital Soil Mapping: A State of the Art $\ldots \ldots \ldots \ldots \ldots \ldots$ P. Lagacherie

2 Digital Soil Mapping Technologies for Countries with Sparse Data

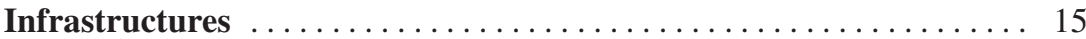
Budiman Minasny, Alex. B. McBratney and R. Murray Lark

3 A New Global Demand for Digital Soil Information S.E. Cook, A. Jarvis and J.P. Gonzalez

4 Development and Application of Digital Soil Mapping Within Traditional Soil Survey: What will it Grow Into?

D. Howell, Y.G. Kim and C.A. Haydu-Houdeshell

5 Soil Map Density and a Nation's Wealth and Income

Alfred E. Hartemink

\section{Part II Dealing with Limited Spatial Data Infrastructures}

6 Digital Soil Mapping as a Component of Data Renewal for Areas with Sparse Soil Data Infrastructures

D.G. Rossiter

7 Challenges to Digital Soil Mapping J.W. Hempel, R.D. Hammer, A.C. Moore, J.C. Bell, J.A. Thompson and M.L. Golden,

8 Mapping Potassium Availability from Limited Soil Profile Data in

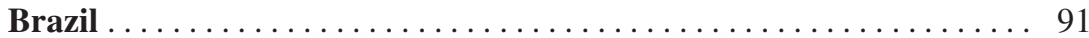
R.B. Prado, V.M. Benites, P.L.O.A. Machado, J.C. Polidoro, R.O. Dart and A. Naumov 
9 GIS as a Support to Soil Mapping in Southern Brazil . . . . . . . . . . . 103

E. Weber, H. Hasenack, C.A. Flores, R.O. Pötter and P.J. Fasolo

10 Experiences with Applied DSM: Protocol, Availability, Quality and

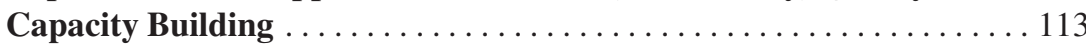
R.A. MacMillan

11 Towards a Data Quality Management Framework for Digital Soil

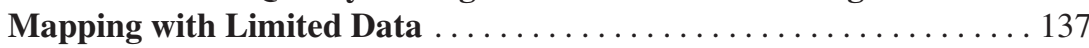
B.G.C.M. Krol

12 Demand-Driven Land Evaluation I.L.Z. Bacic

\section{Part III Digital Soil Mapping - Methodologies}

13 Diffuse Reflectance Spectroscopy as a Tool for Digital Soil Mapping . 165

R.A. Viscarra Rossel and A.B. McBratney

14 Digital Soil Mapping at a National Scale: A Knowledge and GIS Based Approach to Improving Parent Material and Property Information

R. Lawley and B. Smith

15 3D Modelling of Geology and Soils - A Case Study from the UK . . . . 183

B. Smith, H. Kessler, A.J. Scheib, S.E. Brown, R.C. Palmer, O. Kuras,

C. Scheib and C.J. Jordan

16 Landsat Spectral Data for Digital Soil Mapping

J.L. Boettinger, R.D. Ramsey, J.M. Bodily, N.J. Cole, S. Kienast-Brown,

S.J. Nield, A.M. Saunders and A.K. Stum

17 From a Large to a Small Scale Soil Map: Top-Down Against Bottom-Up Approaches . . . . . . . . . . . . . . . . 203 F. Carré, H.I. Reuter, J. Daroussin and O. Scheurer

18 An Approach to Removing Uncertainties in Nominal Environmental

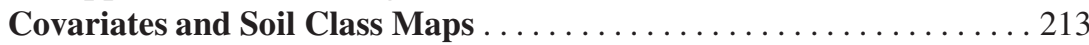
T. Behrens, K. Schmidt and T. Scholten

19 Digital Soil Mapping Using Logistic Regression on Terrain Parameters for Several Ecological Regions in Southern Brazil . . . . . . 225 E. Giasson, S.R. Figueiredo, C.G. Tornquist and R.T. Clarke 
20 Purposive Sampling for Digital Soil Mapping for Areas with Limited Data . . . . . . . . . . . . . . . . . . . . . . . . . . . . 233

A. Xing Zhu, Lin Yang, Baolin Li, Chengzhi Qin, Edward English, James E. Burt and Chenghu Zhou

21 Assessment of Land Degradation Using NASA GIMMS: A Case

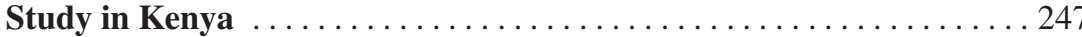

D.L. Dent and Z.G. Bai

\section{Part IV Digital Soil Mapping - Examples}

22 Spatial-Temporal Changes in Land Cover, Soil Properties and Carbon Stocks in Rio de Janeiro

A.P.D. Turetta, M.L. Mendonça-Santos, L.H.C. Anjos and R.L.L. Berbara

23 Broad-Scale Soil Monitoring Through a Nationwide Soil-Testing Database . . . . . . . . . . . . . . . . . . . . . . . . . . . . . . . . . 273 B. Lemercier, D. Arrouays, S. Follain, N.P.A. Saby, C. Schvartz and C. Walter

24 Online Soil Information Systems - Recent Australian Experience . . . . 283 N.J. McKenzie, D.W. Jacquier and L.J. Gregory

25 Digital Soil Mapping Using Legacy Data in the Eden Valley, UK . . . . . 291 T.R. Mayr, R.C. Palmer and H.J. Cooke

26 Delineating Acidified Soils in the Jizera Mountains Region Using

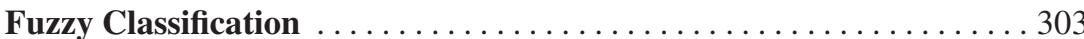

L. Boruvka, L. Pavlu, R. Vasat, V. Penizek and O. Drabek

27 Incorporating Legacy Soil pH Databases into Digital Soil Maps . . . . 311 S.J. Baxter and D.M. Crawford

28 The Digital Terrain Model as a Tool for Improved Delineation of Alluvial Soils

V. Penizek and L. Boruvka 
29 Building a Digital Soil Data Base of the Solimões River Region in the Brazilian Central Amazon

W.G. Teixeira, W. Arruda, H.N. Lima, S.A. Iwata and G.C. Martins

30 Enhancing the Use of Remotely-Sensed Data and Information for Digital Soilscape Mapping . . . . . . . . . . . . . . . . . . . . 337

L. Le Du-Blayo, P. Gouéry, T. Corpetti, K. Michel, B. Lemercier and C. Walter

31 The Use of GIS and Digital Elevation Model in Digital Soil Mapping - A Case Study from São Paulo, Brazil . . . . . . . . . . . . . 349 G.S. Valladares and M.C. Hott

32 Geomorphometric Attributes Applied to Soil-Landscapes Supervised Classification of Mountainous Tropical Areas in Brazil:

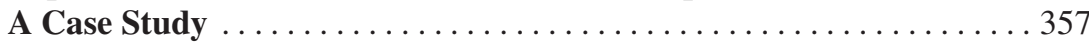
W. Carvalho Junior, E.I. Fernandes Filho, C.A.O. Vieira, C.E.G.R. Schaefer and C.S. Chagas

33 Digital Soil Mapping of Soil Properties in Honduras Using Readily Available Biophysical Datasets and Gaussian Processes . . . . . . . . 367 Juan Pablo Gonzalez, Andy Jarvis, Simon E. Cook, Thomas Oberthür, Mauricio Rincon-Romero, J. Andrew Bagnell and M. Bernardine Dias

34 Digital Mapping of Soil Classes in Rio de Janeiro State, Brazil:

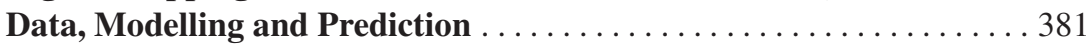
M.L. Mendonça-Santos, H.G. Santos, R.O. Dart and J.G. Pares

\section{Part V Priorities in Digital Soil Mapping}

35 Synthesis and Priorities for Future Work in Digital Soil Mapping . . . 399 F. Carré and J.L. Boettinger

Colour Plate Section 


\section{Contributors}

Anjos, L.H.C.

Universidade Federal Rural do Rio de Janeiro, BR 465 - Km47, Seropédica, RJ, Brazil, CEP 23890-000, lanjos@ufrrj.br

Arrouays, D.

INRA Unité INFOSOL, 2163 avenue de la pomme de pin, BP 20619 Ardon, F-45166 Olivet Cedex, France, Dominique.Arrouays@orleans.inra.fr

Arruda, W.

Instituto Nacional de Pesquisas da Amazônia - INPA - Manaus. Av. André Araújo - 2936, Manaus - AM, 69060-001

Bacic, I.L.Z.

Epagri/Ciram - Empresa de Pesquisa Agropecuária e Extensão Rural de Santa Catarina S.A., Centro de Informações de Recursos Ambientais e de Hidrometeorologia de Santa Catarina, Rodovia Admar Gonzaga 1347, C.P. 502. 88034-901, Florianópolis, Santa Catarina, Brazil, bacic@epagri.sc.gov.br

Bagnell, J.A.

Robotics Institute, Carnegie-Mellon University, Pittsburgh, Pennsylvania, USA, bagnell2@andrew.cmu.edu

Bai, Z.G.

ISRIC - World Soil Information, P.O. Box 353, 6700 AJ, Wageningen, The Netherlands, zhanguo.bai@wur.nl

Baxter, S.J.

Department of Soil Science, The University of Reading, Whiteknights, P.O. Box 233, Reading, England, RG6 6DW, UK, sam.baxter2@googlemail.com

Behrens, T.

Department of Physical Geography, Institute of Geography, University of Tübingen, Tübingen, Germany, thorsten.behrens@uni-tuebingen.de

Bell, J.C.

Department of Soil, Water and Climate, Borlaug Hall, 1991 Upper Buford Circle, St. Paul, MN 55108, jaybell@umn.edu 
Benites, V.M.

Embrapa Soils, Rua Jardim Botanico, 1024, Jardim Botanico, Rio de Janeiro, RJ, Brazil, CEP 22460-000, vinicius@ cnps.embrapa.br

Berbara, R.L.L.

Universidade Federal Rural do Rio de Janeiro, BR 465 - Km47, Seropédica, RJ, Brazil, CEP 23890-000, berbara@ufrrj.br

Bodily, J.M.

USDA Natural Resources Conservation Service, 340 N 600 E, Richfield, UT 84701-2258, Jedd.Bodily@ut.gov.usda

Boettinger, J.L.

Department of Plants, Soils, and Climate, Utah State University, 4820 Old Main Hill, Logan, UT 84322-4820, USA, Janis.Boettinger@usu.edu

Boruvka, L.

Department of Soil Science and Geology, Czech University of Life Sciences in Prague, CZ-165 21, Prague 6 - Suchdol, Czech Republic, Boruvka@af.czu.cz

Brown, S.E.

British Geological Survey, Sir Kinsley Dunham Centre, Keyworth, Nottingham, NG12 5GG, UK

Burt, J.E.

Department of Geography, University of Wisconsin, Madison, Wisconsin, USA, jeburt@wisc.edu

Carré, F.

European Commission, Directorate General Joint Research Centre, Land Management \& Natural Hazards Unit, TP 280, 21020 Ispra (VA), Italy, Florence.Carre@jrc.it

Carvalho Junior, W.

Embrapa Solos, Rua Jardim Botânico, 1024. Rio de Janeiro, RJ, Brazil, CEP 22.460-000,waldircj@cnps.embrapa.br

Chagas, C.S.

Embrapa Solos, Rua Jardim Botânico, 1024. Rio de Janeiro, RJ, Brazil, CEP 22.460-000, chagas.rj@gmail.com

Clarke, R.T.

Hydraulic Research Institute (IPH), Federal University of RioGrande do Sul (UFRGS). Av. Bento Gonçalves, 9500, Porto Alegre, RS, Brazil, 91501-970, clarke@iph.ufrgs.br

Cole, N.J.

USDA Natural Resources Conservation Service, 621 W Fetterman St., Buffalo, WY 82834 
Cook, S.E.

International Centre for Tropical Agricultura (CIAT), AA6713, Cali, Colombia, s.cook@cgiar.org

Cooke, H.J.

Cranfield University, National Soil Resources Institute, Building 37, Cranfield MK43 0AL, UK, h.cook@cranfield.ac.uk

Corpetti, T.

Equipe COSTEL, UMR CNRS 6554 (Littoral Environnement Télédétection et Géomatique), Université de Rennes 2, place du recteur H. le Moal, 35043 Rennes cedex France, thomas.corpetti@uhb.fr

Crawford, D.M.

Department of Primary Industries, Primary Industries Research Victoria, Werribee Centre, 621 Sneydes Road, Werribee, Victoria, 3030, Australia, Doug.Crawford@dpi.vic.gov.au

Daroussin, J.

Unité Science du Sol, INRA Centre d'Orléans, Avenue de la Pomme de Pin, BP 20619 Ardon, 45166 OLIVET Cedex, France, Joel.Daroussin@ orleans.inra.fr

Dart, R.O.

Embrapa's fellowship grant, EMBRAPA Solos - Brazilian Agricultural Research Corporation, The National Centre of Soil Research, Rua Jardim Botânico 1024.

Rio de Janeiro, RJ, Brazil, CEP 22.460-000, rdart81@yahoo.com.br

Dent, D.L.

ISRIC - World Soil Information, P.O. Box 353, 6700 AJ, Wageningen, The

Netherlands, david.dent@wur.nl

Dias, M.B.

Robotics Institute, Carnegie-Mellon University, Pittsburgh, Pennsylvania, USA, bdias@andrew.cmu.edu

Drabek, O.

Department of Soil Science and Geology, Czech University of Life Sciences in Prague, CZ-165 21, Prague 6 - Suchdol, Czech Republic, Drabek@af.czu.cz

English, E.

Department of Geography, University of Wisconsin, Madison, Wisconsin, USA, EEnglish@wisc.edu

Fasolo, P.J.

Embrapa Florestas, Estrada da Ribeira Km 11, CP. 319, CEP 83411-000, Colombo, PR, Brazil

Figueiredo, S.R.

Soil Science Graduate School of the Federal University of Rio Grande do Sul (UFRGS). Av. Bento Gonçalves, 7712, Porto Alegre, RS, Brazil, 90.001-970 
Filho, E.I.F.

Universidade Federal de Viçosa. Avenida Peter Henry Rolfs, s/n, Campus

Universitário. CEP 36570-000. VIÇOSA - MG. Brazil, elpidio@ufv.br

Flores, C.A.

Embrapa Clima Temperado, BR 392 Km 78, CP. 403, CEP 96001-970, Pelotas,

RS, Brasil, flores@cpact.embrapa.br

Follain, S.

UMR LISAH SupAgro/INRA/IRD, 2 place Pierre Viala, F-34060 Montpellier

Cedex 1, France, Follain@supagro.inra.fr

Giasson, E.

Department of Soils of the Federal University of Rio Grande do Sul (UFRGS). Av. Bento Gonçalves, 7712, Porto Alegre, RS, Brazil, 90.001-970, giasson@ufrgs.br

Golden, M.L.

USDA Natural Resources Conservation Service, Rm. 4252-S P.O. Box 2890,

Washington, DC 20013-2890, Micheal.golden@wdc.usda.gov

Gonzalez, J.P.

Robotics Institute, Carnegie-Mellon University, Pittsburgh, Pennsylvania, USA, jpgonzal@cmu.edu

Gouéry, P.

Equipe développement, Centre de Ressource Informatique, Université de Rennes 2, place du recteur H. le Moal, 35043 Rennes cedex France, pascal.gouery@uhb.fr

Gregory, L.J.

CSIRO Land and Water, G.P.O. Box 1666, Canberra, ACT 2602, Australia

Hammer, R.D.

USDA Natural Resources Conservation Service, 100 Centennial Mall North, Federal Bldg, Rm 152, Lincoln, NE 68508, david.hammer@lin.usda.gov

Hartemink, A.E.

ISRIC - World Soil Information, P.O. Box 353, 6700 AJ, Wageningen, The Netherlands, alfred.hartemink@wur.nl

Hasenack, $\mathrm{H}$.

Universidade Federal do Rio Grande do Sul, Centro de Ecologia, CP. 15007, CEP 91501-970, Porto Alegre, RS, Brasil, hasenack@ecologia.ufrgs.br

Haydu-Houdeshell, C.A.

USDA Natural Resources Conservation Service, 14393 Park Avenue, Suite 200

Victorville, CA 92392, Carrie-Ann.Houdeshell@ca.usda.gov

Hempel, J.W.

USDA Natural Resources Conservation Service, 157 Clark Hall Annex, P.O. Box 6301, Morgantown, WV 26506,jon.hempel@wv.usda.gov 
Hott, M.C.

EMBRAPA National Dairy Cattle Research Center, 610 Eugênio do Nascimento

Street, Juiz de Fora, MG, Brazil 36038-330, hott@cnpgl.embrapa.br

Howell, D.

USDA Natural Resources Conservation Service, 1125 16th Street, Room 219

Arcata, CA, USA 95521, David.Howell@ca.usda.gov

Iwata, S.

Petrobras - UNBSOL - Manaus. Rua Darcy Vargas, 645, Parque 10 de Novembro, Manaus - AM

Jacquier, D.W.

CSIRO Land and Water, G.P.O. Box 1666, Canberra, ACT 2602, Australia

Jarvis, A.

International Centre for Tropical Agricultura (CIAT), AA6713, Cali, Colombia;

Bioversity International, Regional Office for the Americas, Cali, Colombia,

a.jarvis@cgiar.org

Jordan, C.J.

British Geological Survey, Sir Kinsley Dunham Centre, Keyworth, Nottingham, NG12 5GG, UK

Kessler, H.

British Geological Survey, Sir Kinsley Dunham Centre, Keyworth, Nottingham, NG12 5GG, UK

Kienast-Brown, S.

USDA Natural Resources Conservation Service, Department of Plants, Soils, and Climate, Utah State University, 4820 Old Main Hill, Logan, UT 84322-4820, USA, Suzann.kienast@ut.usda.gov

Kim, Y.G.

Humboldt State University, Department of Mathematics, Arcata, CA, USA 95521, ygk1@humboldt.edu

Krol, B.G.C.M.

International Institute for Geo-Information Science and Earth Observation (ITC),

Postbus 6, 7500 AA, Enschede, The Netherlands, krol@itc.nl

Kuras, O.

British Geological Survey, Sir Kinsley Dunham Centre, Keyworth, Nottingham, NG12 5GG, UK

Lagacherie, $\mathrm{P}$.

INRA Laboratoire d'étude des Interactions Sol Agrosystème Hydrosystème (LISAH), 2 place Viala 34060 Montpellier cedex 1, France, lagache@supagro.inra.fr 
Lark, R.M.

Environmetrics Group, Biomathematics and Bioinformatics Division Rothamsted Research, Harpenden Hertfordshire AL5 2JQ, UK, murray.lark@bbsrc.ac.uk

Lawley, R.

British Geological Survey, Nottingham, NG12 5GG UK, rslaw@bgs.ac.uk

Le Du-Blayo, L.

Equipe COSTEL, UMR CNRS 6554 (Littoral Environnement Télédétection et Géomatique), Université de Rennes 2, place du recteur H. le Moal, 35043 Rennes cedex France, laurence.ledu@uhb.fr

Lemercier, B.

UMR Sol-Agro et hydrosystème-Spatialisation INRA/Agrocampus Rennes, 65 rue de Saint-Brieuc, CS 84215, F-35042 Rennes Cedex, France, Blandine.Lemercier@agrocampus-rennes.fr

Li, B.

State Key Lab of Resources and Environmental Information System, Institute of Geographical Sciences and Natural Resources Research, Chinese Academy of Sciences, Beijing, China, libl@1reis.ac.cn

Lima, H.N.

Universidade Federal do Amazonas - UFAM - Manaus. Av. Gen. Rodrigo Octávio Jordão Ramos - 3000, Manaus - AM, 69077-000

Machado, P.L.O.A

Embrapa Rice and Beans, Rodovia GO-462, Km 12, CEP: 73075-000 Goiania, GO,Brazil pmachado@cnpaf.embrapa.br

MacMillan, R.A.

LandMapper Environmental Solutions Inc., 7415118 A Street NW, Edmonton, Alberta, Canada, T6G 1V4, bobmacm@telusplanet.net

Martins, G.C.

Embrapa Amazônia Ocidental, Rod AM 010, Km 29 Manaus AM, 69011- 970, Brazil.lau@cpaa.embrapa.br

Mayr, T.R.

Cranfield University, National Soil Resources Institute, Building 37, Cranfield MK43 0AL, UK, t.mayr@cranfield.ac.uk

McBratney, A.B.

Faculty of Agriculture, Food \& Natural Resources, The University of Sydney, JRA McMillan Building A05, NSW 2006, Australia, a.mcbratney@usyd.edu.au 
McKenzie, N.J.

CSIRO Land and Water, G.P.O. Box 1666, Canberra, ACT 2602, Australia, Neil.McKenzie@csiro.au

Mendonça-Santos, M.L.

EMBRAPA - Brazilian Agricultural Research Corporation', The National Center of Soil Research - CNPS, Rua Jardim Botânico, 1024. Jardim Botânico, Rio de Janeiro, RJ, Brazil, CEP 22460-000. mendonca@cnps.embrapa.br

Michel, K.

UMR 5600 (Ville, Environnement, Société), Laboratoire de Biogéographie,

Ecole Normale Supérieure des Lettres et Sciences Humaines, France, kristell.michel@ens-lsh.fr

Minasny, B.

Faculty of Agriculture, Food \& Natural Resources, The University of Sydney, JRA McMillan Building A05, NSW 2006, Australia, b.minasny@usyd.edu.au

Moore, A.C.

USDA Natural Resources Conservation Service, 157 Clark Hall Annex, P.O. Box 6301 Morgantown, WV 26506, Amanda.moore@wv.usda.gov

Naumov, A.

International Potash Institute (IPI), P.O. Box 569, CH-8810, Horgen, Switzerland, alnaumov@geogr.msu.ru

Nield, S.J.

USDA Natural Resources Conservation Service, 100 E B St., Casper, WY 82601-1962, Shawn.Nield@wy.usda.gov

Oberthür, T.

International Centre for Tropical Agricultura (CIAT), AA6713, Cali, Colombia, t.oberthur@cgiar.org

Palmer, R.C.

Fircroft, Sandy Lane, Stockton-on-the-Forest, York, Y032 9UU, UK; Cranfield University, National Soil Resources Institute, Building 37, Cranfield MK43 0AL, UK, RC.Plamer@btinternet.com,r.c.palmer@cranfield.ac.uk

Pares, J.G.

Embrapa's fellowship grant, EMBRAPA Solos - Brazilian Agricultural Research Corporation, The National Centre of Soil Research, Rua Jardim Botânico 1024. Rio de Janeiro, RJ, Brazil, CEP 22.460-000, enhancer@terra.com.br

Pavlu, L.

Department of Soil Science and Geology, Czech University of Life Sciences in Prague, CZ-165 21, Prague 6 - Suchdol, Czech Republic, Pavlu@af.czu.cz

Penizek, V.

Department of Soil Science and Geology, Czech University of Life Sciences in Prague, CZ-165 21, Prague 6 - Suchdol, Czech Republic, Penizek@af.czu.cz 
Polidoro, J.C.

Embrapa Soils, Rua Jardim Botanico, 1024, Jardim Botanico, Rio de Janeiro, RJ, Brazil, CEP 22460-000, polidoro@cnps.embrapa.br

Pötter, R.O.

Embrapa Florestas, Estrada da Ribeira Km 11, CP. 319, CEP 83411-000, Colombo, PR, Brazil

Prado, R.B.

Embrapa Soils, Rua Jardim Botanico, 1024, Jardim Botanico, Rio de Janeiro, RJ,

Brazil, CEP 22460-000, rachel@cnps.embrapa.br

Qin, C.

State Key Lab of Resources and Environmental Information System, Institute of Geographical Sciences and Natural Resources Research, Chinese Academy of Sciences, Beijing, China, qincz@1reis.ac.cn

Ramsey, R.D.

Department of Wildland Resources, Utah State University, 5230 Old Main Hill, Logan, UT 84322-5230, USA, Doug.Ramsey@usu.edu

Reuter, H.I.

European Commission, Directorate General Joint Research Centre, Land Management \& Natural Hazards Unit, TP 280, 21020 Ispra (VA), Italy, Hannes.Reuter@jrc.it

Rincon-Romero, M.

Faculty of Engineering, Universidad del Valle, Cali, Colombia, maurorin@univalle.edu.co

Viscarra, Rossel, R.A.

CSIRO Land and Water, Bruce E. Butler Laboratory, GPO Box 1666, Canberra ACT 2601, Australia, raphael.viscarra-rossel@ csiro.au

Rossiter, D.G.

International Institute for Geo-information Science \& Earth Observation (ITC), Postbus 6, 7500 AA Enschede, The Netherlands, rossiter@itc.nl

Saby, N.

INRA Unité INFOSOL, 2163 avenue de la pomme de pin, BP 20619 Ardon, F-45166 Olivet Cedex, France, Nicolas.Saly@orleans.inra.fr

Santos, H.G.

Researcher at EMBRAPA Solos -Brazilian Agricultural Research Corporation, The National Centre of Soil Research. Rua Jardim Botânico 1024. Rio de Janeiro, RJ, Brazil, CEP 22.460-000, Brazil.humberto@cnps.embrapa.br

Saunders, A.M.

USDA Natural Resources Conservation Service, 101 Aupuni St. Ste. 229, Hilo, HI 96720-4261, Amy.Saunders@hi.usda.gov 
Schaefer, C.E.G.R.

Universidade Federal de Viçosa. Avenida Peter Henry Rolfs, s/n, Campus

Universitário. CEP 36570-000. VIÇOSA - MG. Brazil, carlos.schaefer@ufv.br

Scheib, A.J.

British Geological Survey, Sir Kinsley Dunham Centre, Keyworth, Nottingham, NG12 5GG, UK

Scheib, C.

British Geological Survey, Sir Kinsley Dunham Centre, Keyworth, Nottingham, NG12 5GG, UK

Scheurer, O.

Département Agronomie, Institut Polytechnique LaSalle Beauvais, BP 30313, 60026 Beauvais Cedex, France, Olivier.Scheurer@lasalle-beauvais.fr

Schmidt, K.

University of Tübingen, Institute of Geography, Department of Physical Geography, Tübingen, Germany, karsten.schmidt@uni-tuebingen.de

Scholten, T.

University of Tübingen, Institute of Geography, Department of Physical Geography, Tübingen, Germany, thomas.scholten@uni-tuebingen.de

Schvartz, C.

ISA Lille, Laboratoire Sols et Environnement, 48 Boulevard Vauban, F-59046 Lille Cedex, France, c.Schvartz@isa.lille.fr

Smith, B.

British Geological Survey, Sir Kinsley Dunham Centre, Keyworth, Nottingham, NG12 5GG UK, b.smith@bgs.ac.uk

Stum, A.K.

USDA Natural Resources Conservation Service, 340 N 600 E, Richfield, UT 84701-2258, Alex.Stum@ut.usda.gov

Teixeira, W.G.

Embrapa Amazônia Ocidental - Rod AM 010 - Km 29 - Manaus - AM, 69011 970, wenceslau@cpaa.embrapa.br

Thompson, J.A.

West Virginia University, P.O. Box 6108, Morgantown, WV 26506-6108, james.thompson@mail.wvu.edu

Tornquist, C.G.

Soil Science Graduate School of the Federal University of Rio Grande do Sul (UFRGS). Av. Bento Gonçalves, 7712, Porto Alegre, RS, Brazil, 90.001-970, carlostornquist@terra.com.br 
Turetta, A.P.D.

Brazilian Agricultural Research Corporation - EMBRAPA Solos, Rua Jardim Botânico, 1024. Jardim Botânico, Rio de Janeiro, RJ. Brazil, CEP 22460-000, anaturetta@cnps.embrapa.br

Valladares, G.S.

EMBRAPA National Satellite Monitoring Research Center, 303 Soldado Passarinho Avenue, Campinas, SP, Brazil, 13070-115, gustavo@cnpm.embrapa.br

Vasat, R.

Department of Soil Science and Geology, Czech University of Life Sciences in Prague, CZ-165 21, Prague 6 - Suchdol, Czech Republic, Vasat@af.czu.cz

Vieira, C.A.O.

Universidade Federal de Viçosa. Avenida Peter Henry Rolfs, s/n, Campus Universitário. CEP 36570-000. VIÇOSA - MG. Brazil, carlos.vieira@ufv.br

Walter, C.

UMR Sol-Agronomie-Spatialisation INRA/Agrocampus Rennes, 65 rue de SaintBrieuc, CS 84215, F-35042 Rennes Cedex, France, Christian.Walter@agrocampusrennes.fr

Weber, E.

Universidade Federal do Rio Grande do Sul, Centro de Ecologia, CP. 15007, CEP 91501-970, Porto Alegre, RS, Brasil, eweber@portoweb.com.br

Yang, L.

State Key Lab of Resources and Environmental Information System, Institute of Geographical Sciences and Natural Resources Research, Chinese Academy of Sciences, Beijing, China, yangl@lreis.ac.cn

Zhou, C.

State Key Lab of Resources and Environmental Information System, Institute of Geographical Sciences and Natural Resources Research, Chinese Academy of Sciences, Beijing, China, zhouch@1reis.ac.cn Zhu, A.-X.

State Key Lab of Resources and Environmental Information System, Institute of Geographic Sciences and Natural Resources Research, Chinese Academy of Sciences, Beijing, China; Department of Geography, University of Wisconsin, Madison, Wisconsin, USA, azhu@wisc.edu, axing@1reis.ac.cn 